\title{
The Effectiveness of Local Wisdom-Based Teaching Materials in Enhancing Creative Writing Skills of Elementary School Students
}

\author{
Agus Budi Santosa, Yudi Basuki, Ari Metalin Ika Puspita \\ STKIP PGRI Trenggalek, Indonesia \\ e-mail:agus.budiku@gmail.com,jude.q13@gmail.com \\ arimetalinikapuspita@stkippgritrenggalek.ac.id
}

\begin{abstract}
This study aims at describing the effectiveness of local wisdom-based teaching materials on the creative writing skills of elementary school students. The sample of the study was $2^{\text {nd }}$ grade students at SDN 1 Campurdarat, which amounted to 45 students. The research design uses quasi-experimental research in the form of a nonrandomized control group pretestposttest design. The data were collected using the instrument of creative writing skills. The analysis was performed by different tests using the Wilcoxon formula. The results showed that there were differences before and after the use of teaching materials based on local wisdom towards students' creative writing skills. The results of evaluating creative writing on each learning from learning 1 to 6 show the students' mastery in achieving creative writing criteria.
\end{abstract}

Keywords: creative writing skills, local wisdom, teaching material

\section{INTRODUCTION}

Education is an effort to allow students to be independent with their abilities. Education is consciously carried out to translate the actual and ideal things to achieve excellent and ideal human beings that suit to the goals of education and life (Mudyaharjo, 
2012; Muhmidayeli, 2011). Therefore, the quality of education must always be improved by the challenges and needs in preparing qualified and competitive human resources. An improvement in the quality of education must also be in line with an effort to protect the culture of Indonesia, which began to be replaced with foreign cultures with its westernization. Suharni (2019) said that westernization is an excessive imitation of Westernstyle by adopting their overall pattern of life without any filter filtering it, imitating all aspects of life both in terms of fashion, behaviour, culture and others, on the other hand, the attitude of imitators who undermined customs, culture and national languages. The cooperation between countries and the massive influence of globalization give not only benefits but also adverse impacts that threaten Indonesian culture. Indonesian culture began to be displaced by foreign cultures such as TV shows, exposing adolescents with foreign styles and cultures and reducing their interest in Indonesian regional art (Surahman, 2017). Looking at this, learners should be directed early on to get closer and be familiar with their regional culture. Every region in Indonesia has values that are worth internalizing. Therefore, it is essential to include local wisdom as the main content in teaching materials at elementary schools.

Teaching materials based on local wisdom serve as a means of internalizing cultural values and more comfortable to understand because it is more contextual, close to students' learning environments, as well as being able to enhance learning outcomes (Anggramayeni, Yolida, \& Marpaung, 2018; Zinnurain \& Muzanni, 2018). Teaching materials based on local wisdom will be more useful if it does not only contain local cultural values but is also able to improve survival skills needed in the 21 st century. One of the skills required is a creativity that can be applied in writing. According to Sardila (2016), writing activity is an expressive skill of the results of thoughts and feelings that can be expressed through the activity of moving fine motor through the strokes of the hand to train the productive skills of the process of producing real work. In essence, writing is the expression of an idea as a form of communicating the elements which include self-expression, something general conveyed to the reader, rules and behaviour, and ways of learning (Gere, 1985; Karsana, 2002). It means that writing is also a skill to practice creativity in thinking, as outlined in a written form. However, writing at the elementary school level does not yet have variations in using learning resources and media so that student creativity does not develop (Yarmi, 2014).

Based on the description above and the results of previous studies, the researchers felt the need to conduct applied research to find out the effectiveness of the application of teaching materials based on local wisdom on students' creative writing skills at SD Negeri 1 Campurdarat. The purpose of this study is to test the effectiveness of teaching materials based on local wisdom in improving the creative writing skills of elementary school students.

\section{LITERATURE REVIEW}

Teaching materials have an essential role in achieving the learning objectives that have been planned. Teaching materials are information, tools and texts needed by the teacher/instructor for planning and studying the implementation of learning arranged systematically based on competencies that will be mastered by students in the learning 
process (Prastowo, 2014; Sofan \& Ahmadi, 2010). Teaching materials used in learning not only apply books from the government, but teachers can also develop teaching materials based on local wisdom. Local wisdom is often also called: 'local wisdom', 'people' knowledge, 'local knowledge', 'folk knowledge", indigenous knowledge' or 'traditional wisdom'. Kun (2013) said that local wisdom could be interpreted as local ideas that contain wise, prudent, good value, that is believed and obeyed by the members of the community. Local wisdom is a view of life and science as well as a variety of life strategies in the form of activities carried out by local communities in answering various problems regarding their needs. Maryani \& Yani (2015) said that as a result of local wisdom, everything lived and believed to be true from one generation to the next, serves as a guide for the community on how to behave. Therefore, local wisdom is a value that arises from the thoughts of the community to regulate local life. As quoted from UNESCO (2010) "Indigenous knowledge is local knowledge that is unique to a culture or society".

Creative writing is part of the result or product of creativity because its process involves expressive and productive language skills. Creative writing activities need guidance and an ongoing process. Pranoto (2011) explains that in writing, creative readers are impressed not because of truth, logic, and facts, but on artistic truth measured by intuitive sensitivity. One of the benefits of developing creative writing skills is to train the balance of the right and left brain. Olivia (2012) argues that to stimulate children to learn and write, the natural learning system of the brain is very effective, in fact almost all the potential possessed by a student will be explored and awakened. Olivia (2012) further explained that creative writing activities enable the natural learning system of the brain to occur. Creative writing for children is writing for playing and getting entertainment. Therefore, writing for children is to express pleasant experiences through stories, poems and novels (Kurniawan, 2014). Tarigan (2008) states that writing can be interpreted as an activity revealing ideas using writing language as a media presenter. Writing activities train students in expressing their thoughts or creative ideas so that students are trained to think creatively and are able to convey their ideas through the writing. Creative writing emphasizes on a person's active process to express ideas through unusual means to produce different copyrighted works, not only useful, but also interesting (Gunawan \& Aziz, 2018).

In this study, local wisdom-based teaching materials are designed not only as an introduction to the culture and as a means of strengthening culture to the nation's generation, but also as teaching materials that can improve students' creative writing skills. As an Indonesian citizen who has cultural diversity, teaching materials based on local wisdom can reinforce the local culture and train students to think creatively about their own culture and be able to express it in the form of writing activities. Armariena \& Murniviyanti (2017) states that creative writing with the theme of local wisdom makes it easier to explore ideas because students are accustomed to their living environment with a wise regional culture. Mulyani (2011) states that writing based on local wisdom is a means to implement character education. Therefore, there is a need for understanding culture, and with the power of creativity, it is able to maintain the local culture against the lunge of foreign cultures. 
Agus Budi Santosa, Yudi Basuki, Ari Metalin Ika Puspita

\section{RESEARCH METHODS}

The research approach used in this research is the quantitative research approach. The research method used in this study is Quasi-Experimental Design with a nonrandomized control group pretest-posttest design. Creswell (2012) defines experimental design as a procedure in quantitative studies where investigators want to test whether an activity or ingredient can make a difference in the results of a research subject. Abidin (2015) further explained that experimental research is research used to measure a variable against other variables directly and can test the hypothesis of a causal relationship. This research aims to test whether the teaching materials based on local wisdom can provide a difference between students' creative writing skills so that this research uses the quasi-experiment design. The sampling technique is purposive sampling. Arikunto (2016) explains that purposive sampling is done by taking subjects not based on strata, random, or regions, but based on particular objectives.

\subsection{Subject of The Research}

The subjects in this study were elementary school students grade II at SDN 1 Campurdarat in the academic year 2018/2019 consisting of 45 students. The study was conducted based on learning curriculum 2013 subtheme 1 consisting of learning 1 to 6 using teaching materials based on local wisdom. At each learning activity, the subject is directed towards creative writing activities.

\subsection{Instruments}

The instrument in the research is a test used to collect the research data. The test instrument was validated by three experts, namely a linguist, an assessment expert, and an elementary school children's learning expert. The instrument was then trialled and then analyzed each item. The item analysis is done by testing the instrument followed up by testing the validity of the questions, the reliability of the questions, the distinguishing features, and the level of difficulty of the questions. The cultural literacy test was conducted on 21 grade II students from different schools outside the study sites.

\subsection{Data Analysis}

A comparative test using the formula Paired Sample T-Test was used to determine the effectiveness of teaching materials. It aims to determine differences in student grades before and after using contextual-based thematic teaching materials. Before conducting the comparison test, the assumption test is carried out, namely the normality and homogeneity tests.

\section{FINDINGS}

\subsection{Student Creative Writing Skills}

Research data on creative writing skills were obtained from test instruments given to students. A display of the range of students' creative writing skills in Subtheme 1 is presented in Table 1 as follows. 
The Effectiveness of Local Wisdom-Based Teaching Materials

Table 1 Range of Student Grades in Creative Writing Skills Subtheme 1 SDN 1 Campurdarat

\begin{tabular}{cccc}
\hline No. & Range & Frequency & Percentage (\%) \\
\hline $\mathbf{1}$ & $91-100$ & 24 & 53,3 \\
\hline $\mathbf{2}$ & $81-90$ & 10 & 22,2 \\
\hline $\mathbf{3}$ & $71-80$ & 9 & 20 \\
\hline $\mathbf{4}$ & $61-70$ & 2 & 4,4 \\
\hline $\mathbf{5}$ & $00-51$ & 0 & 0 \\
\hline Total & & 45 & 100 \\
\hline
\end{tabular}

Based on table 4.16 the data obtained from the results of students' creative writing skills tests, there are 24 students or $53.3 \%$ s who score $91-100$. Then students who score 81 90 are 10 students or $22.2 \%$. While as many as 9 students or $20 \%$ get $71-80$ and 2 students or $4.4 \%$ get $61-70$. The difference in the percentage of grades obtained by students can be seen in the Figure Circle Chart as follows.

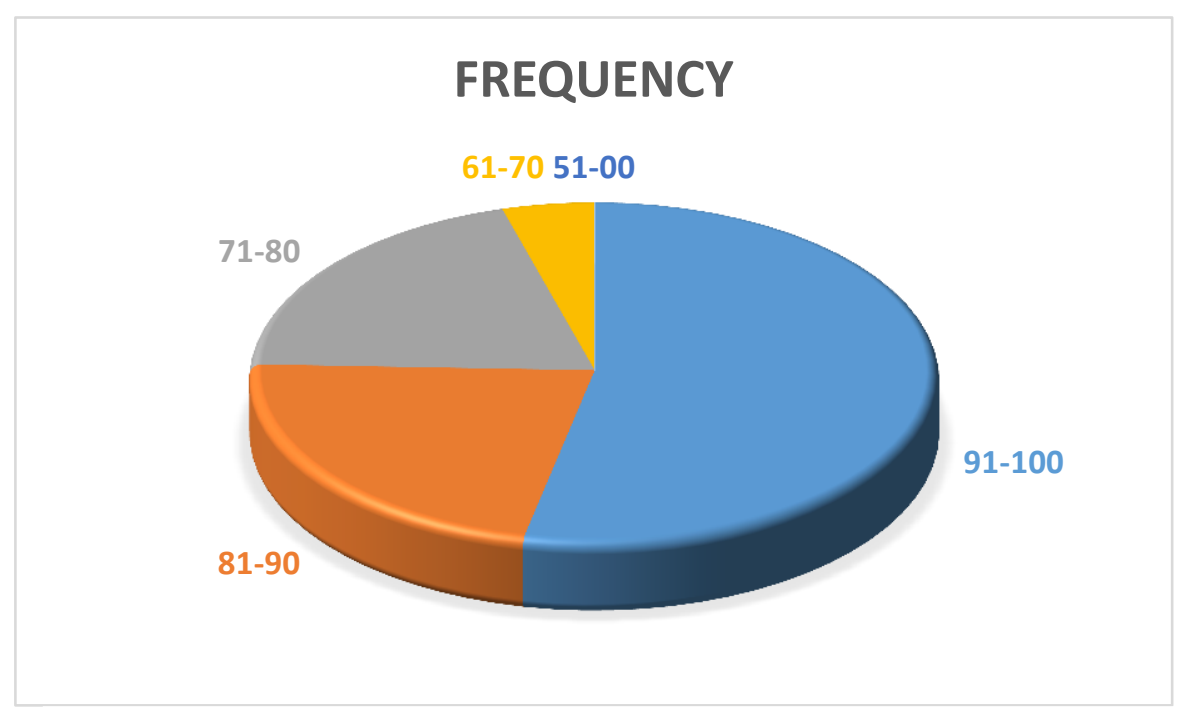

Figure 1 Circle Diagram of Student Creative Writing Skills of SDN 1 Campurdarat

At the end of the sub-theme, students work on evaluation questions aimed at measuring the level of creative writing skills using teaching materials. The following will be presented in Table 2, recapitulation of students' creative writing skills in the field test.

Table 2 Recapitulation of Average Writing Skills in SDN I Campurdarat

\section{Learning Average Class Grade Note}

\begin{tabular}{ccc}
\hline $\mathbf{1}$ & 97,04 & Meet the criteria \\
\hline $\mathbf{2}$ & 93,75 & Meet the criteria \\
\hline $\mathbf{3}$ & 92,29 & Meet the criteria \\
\hline $\mathbf{4}$ & 92,9 & Meet the criteria \\
\hline $\mathbf{5}$ & 94,47 & Meet the criteria \\
\hline $\mathbf{6}$ & 91,68 & Meet the criteria \\
\hline
\end{tabular}

JELTL (Journal of English Language Teaching and Linguistics), 4(3), 2019 
Agus Budi Santosa, Yudi Basuki, Ari Metalin Ika Puspita

Based on Table 2 above, it can be concluded that students' creative writing skills fall into the "Very Good" category. Learning 1 to learning 6 values of the creative writing skills of students are above $90 \%$, and more than $85 \%$ value of creative writing skills are above predetermined criteria.

\subsection{Comparative Test of Creative Writing Skills \\ 4.2.1 Normality Test of Creative Writing Skills}

The normality test of creative writing skills in SDN I Campurdarat is shown in Table 3 as follows.

Table 3 Normality Test of Creative Writing Skills at SDN I Campurdarat

\begin{tabular}{lcrrrrr}
\hline & \multicolumn{3}{c}{ Kolmogorov-Smirnov ${ }^{\text {a }}$} & \multicolumn{3}{c}{ Shapiro-Wilk } \\
\cline { 2 - 7 } & Statistic & Df & Sig. & Statistic & df & \multicolumn{1}{c}{ Sig. } \\
\hline men_kreatif_sdcamp1 & .198 & 44 & .000 & .883 & 44 & .000 \\
men_kreatif_sdcamp2 & .171 & 44 & .003 & .880 & 44 & .000 \\
\hline
\end{tabular}

a. Lilliefors Significance Correction

Based on Table 3 from the results of the normality test using the KolmogorovSmirnov formula, it is known that creative writing skills data before using contextual based teaching materials are not normally distributed because the significance value is below 0.05 $(0.000<0.05)$. Data on creative writing skills after using teaching materials are also not normally distributed, and it is indicated by the significance value, which is below 0.05 (0.003 $<0.05)$. So, the two data are not normally distributed.

\subsubsection{Homogeneity Test of Creative Writing Skills}

The homogeneity test of creative writing skills at SDN I Campurdarat is shown in Table 4 as follows

Table 4 Homogeneity Test of Creative Writing Skills at SDN I Campurdarat

\begin{tabular}{llrrrr}
\hline & & Levene Statistic & df1 & df2 & \multicolumn{2}{c}{ Sig. } \\
\hline men_kre_campr & Based on Mean & 2.070 & 1 & 86 & .154 \\
& $\begin{array}{l}\text { Based on Median } \\
\text { Based on Median and with }\end{array}$ & 1.524 & 1 & 86 & .220 \\
& $\begin{array}{l}\text { adjusted df } \\
\text { Based on trimmed mean }\end{array}$ & 1.524 & 1 & 79.469 & .221 \\
& & 2.011 & 1 & 86 & .160 \\
\hline
\end{tabular}

Based on Table 4, from the homogeneity test of creative writing skills before and after using a statistical calculation based on mean, a significance value of 0.154 was obtained. This shows that the significance value is more than 0.05 , then the research data are homogeneous. 


\subsection{Comparative Test}

From the results of the normality assumption test, it is known that all data are not normally distributed. From the homogeneity test, the research data are homogeneous. Therefore, a paired sample T-test comparison test cannot be performed because the assumption test is not fulfilled. So that the comparison test is performed with the Wilcoxon formula. The creative writing skills test for students of SDN I Campurdarat will be presented in table 5 as follows.

Table 5 Comparative Test of Creative Writing Skills at SDN I Campurdarat Test Statistics

\begin{tabular}{ll}
\hline & $\begin{array}{l}\text { result_bel_sdcamp2 } \\
\text { result_bel_sdcamp1 }\end{array}$ \\
\hline$Z$ & $-5.654^{\mathrm{a}}$ \\
Asymp. Sig. (2-tailed) & .000 \\
\hline a. Based on negative ranks. \\
b. Wilcoxon Signed Ranks Test
\end{tabular}

Based on Table 4.33, the comparative test results with the Wilcoxon formula obtained a significance value of $0,000 \quad(<0.05)$. These results indicate that there are differences between creative writing skills before and after using contextual-based thematic teaching materials.

\section{DISCUSSION}

The implementation of teaching materials based on local wisdom is effective in improving students' creative writing skills. Lesson material that utilizes the surrounding environment makes it easy for students to develop ideas because students already have preliminary knowledge so that they are able to express creative ideas on their own culture. This is based on the results of creative writing ability test showing that $75.5 \%$ students are in a very good category, $20 \%$ included in the good category, while $4.4 \%$ included in the sufficient category. Based on these results, the creative writing skills of grade II students of SDN 1 Campurdarat after being treated using teaching materials based on local wisdom are included in the excellent category.

At each learning, from learning 1 to learning 6 also, creative writing skills are also evaluated. The results of the study showed that in every learning the students got good results; in terms of their achievement of each learning, above $90 \%$ are fulfilling the criteria. Based on the results of research, it is shown that local wisdom-based teaching materials are effective for training creative writing skills. This is reinforced by the results of comparative tests conducted on the results of the pretest and posttest showed a significant difference between before and after the use of teaching materials based on local wisdom.

Teaching materials belong to one of the pivotal components in learning. Learners can develop their knowledge through teaching materials they obtain. Teaching materials that are arranged systematically and contextually for students will make it easier for students to understand. Most of the learning done by teachers still uses standard teaching materials from 


\section{Agus Budi Santosa, Yudi Basuki, Ari Metalin Ika Puspita}

the government, which is still general and far from where students live. This makes children often have difficulty in understanding the lesson because they have to think abstractly about foreign materials that they are not familiar with. Teachers who are not creative also do not have the desire to develop teaching materials based on the needs and situations of students, and teachers still feel burdened with administrative matters. The presence of teaching materials based on local wisdom makes it easy for teachers and students to apply more effective learning. Tilaar (2002) revealed that the environment is the first and main source of learning. Teaching and learning processes that do not pay attention to the environment also do not produce maximum learning outcomes.

The learning process is not only as a means of delivering subject matter focused on achieving knowledge, but it is also used to strengthen the culture. Learning carried out in schools needs to get closer and familiarize students with the local culture, which is a prerequisite for wise values. Therefore, it is necessary to apply teaching materials that contain local wisdom in the region where students learn. Teaching materials based on local wisdom are not only about introducing a past wise culture but also must be able to practice the skills needed at this time, one of which is creativity. Wise local knowledge balanced with creativity will make students able to maintain their own culture while being able to compete in a broader world in the future. Creativity can be expressed in a written form. According to Dalman (2012), writing is a creative process of expressing ideas in the form of written language or story. (

Yunus (2015) said that creative writing emphasizes the active process of someone to win ideas through unusual ways to produce different creative works, which are not only useful but also entertaining. Creative writing skills train students to express their creative ideas. So that students will get used to convey their thoughts through writing activities. Cahyani \& Hodijah (2007) revealed that writing is a very complex skill for a child wherein writing a child will be analogous to the process of thinking, knowledge, skills and strategies that must accompany it.

Other relevant research also shows that teaching materials based on local wisdom influence increasing understanding of culture, character development, and creativity in writing. Research conducted by Armariena \& Murniviyanti (2017) shows that writing short stories based on local wisdom can improve creative writing skills. Other research conducted by Widyaningrum (2018) shows that a fairytale based on local wisdom, making it easier for students to explore ideas and express them in a written form. Also, local wisdom material can develop skills in writing reports, writing scripts, and creative writing (Saputro, 2014; Septarianto, 2016). Based on other relevant research, local wisdom material can improve creative writing skills. In this study, local wisdom is systematically packaged in the form of teaching materials, making it easier for students to understand the lessons and improve students' creative writing skills.

Student creative writing activities of local wisdom material in this study will familiarize learners to think creatively to be able to create a product of his thought. The student writing activities will go through the stages that include acquiring ideas, processing ideas, and producing ideas (Abidin, 2012). The use of local wisdom-based teaching materials directs learners to respond and acquire ideas for environmental phenomena around learners 
so that students are able to take advantage of the initial knowledge they have. The initial understanding by learners was processed at the stage of the idea of processing to find a new idea. At the stage of the idea's processing, learners are trained to think, feel, and imagine, until finally, students reveal the results of ideas processing in the form of creative writing products. In line with the research carried out Rahayu (2016) through student writing activities can explore the reason and connect his experience with the reality contained in the text and beyond the text. The use of local wisdom-based teaching materials trains more inflight learners to develop creativity, understand and explore value in culture, to dare to create new ideas for culture, where learners are directed to looking for new solutions about cultures that should be followed according to cultural rules. The result of Aziz's research (2009) reveals that creative writing can be observed through novelty, breakdown, and form aspects. Creative writing can train learners to discover ideas, develop ideas, and create stories to edit or revise their work (Febriyanti, Harsiati, \& Dermawan, 2017; Nurmina, 2016). In line with the results, local wisdom-based teaching materials direct learners to be able to find thoughtful thinking and solve local cultural issues to make new ideas as a result of thinking. Local wisdom-based teaching materials are meant to be able to maintain the wise local knowledge, and the relevance to the potential of the region (Laksana, Kurniawan, \& Niftalia, 2016; Utari, Degeng, \& Akbar, 2016). In this study, the use of local wisdom-based teaching materials allowed learners to increase cultural knowledge and local potentials to maintain and familiarize themselves with creative ideas to maintain a cultural existence where creative thought results are expressed in creative writing.

\section{CONCLUSION}

Teaching materials based on local wisdom provide contextual learning so that it teaches students with more concrete situations. In this way, it is easier for students to develop their creative ideas and express them in a written form. The results of the study show that local wisdom-based teaching materials are effective for improving creative writing skills. This is based on research findings and different tests showing that almost all students complete the evaluating creative writing test in each learning. It is strengthened by the results of the test of creative writing skills showing that there is a difference before and after the use of local wisdom-based teaching materials. Since this study is conducted in grade 2 students of primary schools, the teacher's role is essential to stimulate students' creative data and writing skills. Thus, the implementation of teaching materials based on local wisdom to improve creative writing skills also needs the role of the teacher to provide direction and motivate students to develop their creative ideas.

\section{REFERENCES}

Abidin, Y, Z. (2015). Metode Penelitian Komunikasi: Penelitian Kuantitatif: Teori dan Aplikasi. Bandung: Pustaka Setia.

Abidin, Yunus. (2012). Pembelajaran Menulis Dalam Gamitan Pendidikan Karakter. EduHumaniora | Jurnal Pendidikan Dasar Kampus Cibiru, 4(1). https://doi.org/10.17509/eh.v4i1.2823

Anggramayeni, A., Yolida, B., \& Marpaung, R. R. T. (2018). Efektivitas Bahan Ajar Berbasis Kearifan Lokal terhadap Aktivitas dan Hasil Belajar Peserta Didik. Jurnal 
Agus Budi Santosa, Yudi Basuki, Ari Metalin Ika Puspita

Bioterdidik: Wahana Ekspresi Ilmiah, 6(5). Retrieved From http://jurnal.fkip.unila.ac.id/index.php/JBT/article/view/16727

Arikunto, S. (2016). Prosedur Penelitian Suatu Pendekatan Praktik. Jakarta: Rineka Cipta.

Armariena, D. N., \& Murniviyanti, L. (2017). Penulisan Cerpen Berbasis Kearifan Lokal

Sumatera Selatan dengan Metode Image Streaming dalam Proses Kreatif Mahasiswa. Jurnal PEMBAHSI (PEMBELAJARAN BAHASA DAN SASTRA INDONESIA), 7(1), 88115. https://doi.org/10.31851/pembahsi.v7i1.1287

Aziz, R. (2009). Pengaruh kegiatan synectics terhadap kemampuan menulis kreatif. Gifted Review: Jurnal Keberbakatan Dan Kreativitas, 3, 1-14.

Cahyani, I., \& Hodijah, H. (t.t.). Kemampuan Berbahasa Indonesia di Sekolah Dasar. Bandung: UPI Press.

Creswell, C. (2012). Educational Research: Planning, Conducting, and Evaluating Quantitative and Qualitative Research (fourth edition). Boston: Pearson.

Dalman, D. (2012). Menulis Karya Ilmiah. . Jakarta: PT Rajagrafindo Persada.

Febriyanti, A. L., Harsiati, T., \& Dermawan, T. (2017). Pengembangan Instrumen Asesmen Menulis Kreatif Cerita Fantasi untuk Siswa Kelas VII SMP (Journal:eArticle, State University of Malang). https://doi.org/10.17977/jptpp.v2i10.10105

Gere, A., R. (1985). Writing and Learning. New York: McMillan Publishing Company.

Gunawan, H. M., \& Aziz, R. (2018). Mengapa Kepercayaan Diri Mempengaruhi Kemampuan Menulis Kreatif Siswa? Psikoislamika, 15(2), 7-11.

Karsana, A. (2002). Keterampilan Menullis. Jakarta: Karunika.

Kun, P. Z. (2013). Pembelajaran Sains Berbasis Kearifan Lokal. PROSIDING: Seminar Nasional Fisika Dan Pendidikan Fisika, 4(1). Retrieved From http://jurnal.fkip.uns.ac.id/index.php/prosfis1/article/view/3316

Kurniawan, H. (2014). Pembelajaran Menulis Kreatif. Bandung: Remaja Rosdakarya.

Laksana, D. N. L., Kurniawan, P. A. W., \& Niftalia, I. (2016). Pengembangan Bahan Ajar Tematik SD Kelas IV Berbasis Kearifan Lokal Masyarakat Ngada. Jurnal Ilmiah Pendidikan Citra Bakti, 3(1), 1-10.

Maryani, E., \& Yani, A. (2015). Local Wisdom of Kampung Naga in Mitigating Disaster and Its Potencies for Education Tourism Destination. ASEAN Journal on Hospitality and Tourism, 14(2), 72-85.

Mudyaharjo, R. (2012). Filsafat Ilmu Pendidikan: Suatu Pengantar. Bandung: PT. Remaja Rosdakarya.

Muhmidayeli, M. (2011). Filsafat Pendidikan. Bandung: PT. Refika Aditama.

Mulyani, M. (2011). Model Pembelajaran Menulis Berbasis Kearifan Lokal yang Berorientasi Pendidikan Karakter Studi Kuasi Eksperimen pada Siswa SMPN 2 Kelas VII, Windusari, Magelang. Pena: Jurnal Pendidikan Bahasa Dan Sastra, 1(1). Retrieved From https://online-journal.unja.ac.id/pena/article/view/1427

Nurmina, N. (2016). Menulis Kreatif Cerita Fiksi Anak. Jurnal Pendidikan Dasar (JUPENDAS), 1(2). Retrieved From http://jfkip.umuslim.ac.id/index.php/jupendas/article/view/145

Olivia, F. (2012). Mencetak Anak Brilian dengan Metode Biowriting. Jakarta: PT Elex Media Komputindo. 
Pranoto, N. (2011). 24 Jam Memahami Creative Writing. Yogyakarta: Kanisius.

Prastowo, A. (2014). Panduan Kreatif Membuat Bahan Ajar Inovatif. Yogyakarta: Diva Press.

Rahayu, E. (2016). Peningkatan Kemampuan Menulis Kreatif Siswa Melalui Strategi Rekayasa Teks. Bahas Unimed, 27(4). https://doi.org/10.24114/bhs.v27i4.5706

Saputro, E. (2014). Pengembangan Bahan Ajar Menulis Berbasis Nilai-Nilai Kearifan Lokal untuk SMP Muhammadiyah 1 Tulang Bawang Tengah Kelas VII Semester 1 (Doctoral Disser). Universitas Lampung, Lampung.

Sardila, V. (2016). Strategi Pengembangan Linguistik Terapan Melalui Kemampuan Menulis Biografi dan Autobiografi: Sebuah Upaya Membangun Keterampilan Menulis Kreatif Mahasiswa. An-Nida', 40(2), 110-117.

Septarianto, T. W. (2016). Pengembangan Buku Pengayaan Menulis Teks Laporan Hasil Observasi yang Bermuatan Kearifan Lokal untuk Peserta Didik Kelas X SMA (Doctoral Dissertation). Universitas Negeri Semarang, Semarang.

Sofan, A., \& Ahmadi, L., K. (2010). Konstruksi Pengembangan Pembelajaran Pengaruhnya terhadap Mekanisme dan praktik kurikulum. Jakarta: Prestasi Pustaka.

Suharni, S. (2019). Westernisasi Sebagai Problema Pendidikan Era Modern. Jurnal ALIJTIMAIYYAH: Media Kajian Pengembangan Masyarakat Islam, 1(1). Retrieved From https://jurnal.ar-raniry.ac.id/index.php/PMI/article/view/255

Surahman, S. (2017). Dampak Globalisasi Media Terhadap Seni dan Budaya Indonesia. Lontar: Jurnal Ilmu Komunikasi, 2(1). https://doi.org/10.30656/lontar.v2i1.334

Tarigan, H. (2008). Menulis sebagai Suatu Keterampilan Berbahasa. Bandung: Angkasa.

Tilaar, H., A, R. (2002). Pendidikan, Kebudayaan, dan Masyarakat Madani Indonesia. Bandung: PT Remaja Rosdakarya.

UNESCO, u. (t.t.). Indigenous Knowledge and Sustainability. Diambil 10 September 2019, dari http://www.unesco.org/education/tlsf/mods/theme_c/mod11.html.

Utari, U., Degeng, I. N. S., \& Akbar, S. (2016). Pembelajaran Tematik Berbasis Kearifan Lokal di Sekolah Dasar dalam Menghadapi Masyarakat Ekonomi Asean (MEA). Jurnal Teori Dan Praksis Pembelajaran IPS, 1(1), 39-44. https://doi.org/10.17977/jtp2ips.v1i1.5861

Widyaningrum, H. K. (2018). Pembelajaran Menulis Teks Cerita Dongeng Berbasis Kearifan Lokal Pada Siswa Kelas IV. Jurnal Pendidikan Edutama, 5(2), 89-96. https://doi.org/10.30734/jpe.v5i2.129

Yarmi, G. (2014). Meningkatkan Kemampuan Menulis Kreatif Siswa Melalui Pendekatan Whole Language dengan Teknik Menulis Jurnal. Perspektif Ilmu Pendidikan, 28(1), 816. https://doi.org/10.21009/PIP.281.2

Yunus, S. (2015). Kompetensi Menulis Kreatif. Bogor: Ghalia Indonesia.

Zinnurain, Z., \& Muzanni, A. (2018). Pengembangan Buku Ajar Berbasis Kearifan Lokal Pada Siswa Kelas V Sekolah Dasar. Jurnal Ilmiah IKIP Mataram, 4(2), 63-69. 